\title{
Curriculum Reform in Indonesia: Moving from an Exclusive to Inclusive Curriculum
}

Amirul Mukminin ${ }^{\star 1}$, Akhmad Habibi $^{1}$, Lantip Diat Prasojo ${ }^{2}$, Abdullah IDI $^{3}$ AND AFRENI HAMIDAH ${ }^{1}$

$\approx$ The goal of education is to foster all students' intellectual, social, and personal potential to their highest level by providing them with an equitable and equal education irrespective of their characteristics (e.g., ethnicity, social class, language use, religion, and other human differences). Different students and communities should not be excluded in terms of curriculum. At the micro-level classroom, student engagement is central. Teachers should go beyond the prescribed curriculum by working with their students and by including their voices. However, how can students be successful academically and socially if the school curriculum is anchored in the mainstream curriculum, primarily promoting the dominant groups? For example, given that the books, curriculum, and standardised testing are centralised in Indonesia, the content is, of course, generalised for all students. Teachers and schools throughout the country should use the same materials for all students. However, for the disadvantaged children coming from poor, rural, and remote areas, such policies lead them to trouble. They learn the books and materials that are similar to those that the affluent schools and students use in cities, but their values and perspectives are excluded. Also, how can students who are racially, culturally, and linguistically marginalised and low-income families succeed if the curriculum is organised exclusively to maintain the current social structure? The purpose of this paper is to explore the need to move from an exclusive to inclusive curriculum in Indonesia so that all students can succeed academically and socially. The orienting questions for this study are: (1) What do we mean by an exclusive and inclusive curriculum? (2) What are the components of an inclusive curriculum? (3) What should be reformed to create an inclusive curriculum? (4) What kind of leadership is required to guide the reform from an exclusive to an inclusive curriculum?

Keywords: curriculum reform, exclusive curriculum, inclusive curriculum, inclusive leadership

$1 \quad{ }^{*}$ Corresponding Author. Graduate School, Faculty of Education, Jambi University, Indonesia; amirul.mukminin@unja.ac.id.

2 Graduate School, Yogyakarta State University, Yogyakarta, Indonesia.

3 Graduate School, Universitas Islam Negeri Raden Fatah, Palembang, South Sumatra, Indonesia. 


\section{Kurikularna prenova v Indoneziji: prehod od izključujočega $\mathrm{k}$ vključujočemu kurikulumu}

Amirul Mukminin, Akhmad Habibi, lantip Diat Prasojo, Abdullah Idi in Afreni Hamidah

$\propto$ Cilj izobraževanja je spodbujanje najvišje ravni vseh intelektualnih, socialnih in osebnih potencialov učencev z zagotavljanjem pravičnega in enakopravnega izobraževanja za vse učence ne glede na njihove značilnosti (npr. etnična pripadnost, družbeni razred, jezikovna raba, religija in druge razlike). Kurikulum naj ne bi izključeval različnih učencev in skupnosti. Na mikroravni, v učilnici, je vključenost učencev osrednjega pomena. Učitelji morajo presegati predpisani učni načrt $\mathrm{z}$ delom $\mathrm{z}$ učenci in vključevanjem njihovih mnenj. Poraja se vprašanje, kako so lahko učenci akademsko in socialno uspešni, če je šolski kurikulum del glavnega kurikuluma, ki predvsem spodbuja prevladujoče skupine. $\mathrm{V}$ ponazoritev navajamo dejstvo, da so knjige, kurikulum in standardizirani testi v Indoneziji centralizirani, kar pomeni, da je vsebina posplošena za vse učence. Učitelji in šole so dolžni uporabljati enaka gradiva za vse učence v vsej državi. Tovrstna politika povzroča težave deprivilegiranim otrokom $\mathrm{z}$ revnih, s podeželskih in $\mathrm{z}$ oddaljenih območij. Ti si kupijo knjige in gradiva, podobna tistim, ki jih uporabljajo premožne šole in učenci v mestih, vendar so njihove vrednote in pogledi pri tem izključeni. Naslednje vprašanje je, kako so lahko uspešni rasno, kulturno in jezikovno marginalizirani učenci in družine z nizkimi dohodki, če je namen kurikuluma izključno ohranjanje trenutne družbene strukture. Namen tega članka je raziskati potrebo po prehodu od izključujočega $\mathrm{k}$ vključujočemu kurikulumu v Indoneziji, da bodo lahko vsi učenci akademsko in socialno uspešni. Usmeritvena vprašanja za to raziskavo so: 1) kako opredelimo izključujoč in vključujoč kurikulum; 2) kateri so sestavini deli vključujočega kurikuluma; 3) kaj bi bilo treba spremeniti, da bi izoblikovali vključujoč kurikulum; 4) kakšno mora biti vodstvo, ki bi usmerjalo reformo z izključujočega v vključujoč kurikulum.

Ključne besede: kurikularna reforma, izključujoč kurikulum, vključujoč kurikulum, vključujoče vodstvo 


\section{Introduction}

Education is essential for every human being. Developing all children's social, intellectual, and personal potential to their uppermost level is the primary mission of education (Bennett, 2003; Nieto \& Bode, 2008) through providing them with an equitable, equal, and high-quality education (Banks, 2002; Nieto \& Bode, 2008) regardless of students' characteristics, including race, ethnicity, social class, language use, gender, sexual orientation, religion, ability, and other human differences. To achieve its mission, at the school level, Ryan (2003) contended that various students and communities should not be excluded in terms of curriculum, patterns of communication or interactions, decision making, and policy considerations. At this level, educational programmes, practices, and policies should address various students' potential. At the micro-level classroom, student engagement is central. Teachers should go beyond the prescribed curriculum by working with their students and by including their voices and experiences (Kamil, Mukminin, Jamin, Yusuf, \& Idrus, 2013; McMahon, 2003). 'Teachers need to deconstruct their curricular content and pedagogical approaches to uncover and move beyond assumptions of neutrality' (McMahon, 2003, p. 259). In addition, McMahon (2003) wrote that student engagement could take place when students have 'a teacher who presents material in an interesting way or who uses a variety of strategies to convey information' (p. 260). Teachers should have high expectations for all students. They should facilitate students to develop their intellectual, social, and personal promises by teaching with various methods and approaches and by not using materials solely from the dominant sides (Mukminin, 2012, 2019; Mukminin \& Mcmahon, 2013). In addition, Olmedo (2003) stated that the schools that could narrow the achievement gap were those that have well-trained and motivated teachers, a culturally sensitive and challenging curriculum, and a school culture promoting high academic achievement among all students. In other words, a school's mission is to support all students in the experience of high academic and social success through being 'empowered not only by studying their own culture but also by being exposed, through a variety of pedagogical perspectives, to different perspectives' (Nieto \& Bode, 2008, p. 338).

However, how can students be successful academically and socially if the school curriculum is anchored in the traditional or mainstream curriculum, which primarily promotes the dominant or elite groups in scope including bias in textbooks, trade books, and other instructional media' (Bennett, 2003, p. 299)? For example, given that the books, curriculum, and standardised testing are centralised in Indonesia, the content is, of course, generalised for all 
Indonesian students. Teachers and schools throughout the country should use the same materials and books for all students (Kamil, Mukminin, Jamin, Yusuf, \& Idrus, 2013; Kamil \& Mukminin, 2015; Kamil, Mukminin, Ahmad, \& Kassim, 2018). However, for the disadvantaged children who come from the poor, rural, and remote areas, these policies lead them to trouble. They learn the books and materials that are similar to those that the affluent schools and students use in cities, but their values and perspectives are excluded. Such policies have led to repetition rates at the primary level that are four times higher among the poorest children than among their richest peers. The poorest children have dropout rates between 2 and 3 per cent compared with rates below 1 per cent for children from high-income families (World Bank, 2006). Such policies, from the perspective of the cultural capital theory, although schools are an apolitical and neutral forum, actually favour the dominant groups through their symbolic representations of cultural domination (Sadovnik, 2007).

Another important question related to the curriculum is how can students who are racially, culturally, and linguistically marginalised and low-income families succeed if the curriculum is organised exclusively in order to maintain the current social structure? The purpose of this paper is to explore the need to move from an exclusive to inclusive curriculum in Indonesia so that all students can succeed academically and socially. The orienting questions for this study are: (1) What do we mean by an exclusive and inclusive curriculum? (2) What are the components of an inclusive curriculum? (3) What should be reformed to create an inclusive curriculum? (4) What kind of prospective leadership is needed to guide the reform from an exclusive to an inclusive curriculum?

\section{Literature Review}

\section{The Educational System in Indonesia}

The educational system in Indonesia, consisting of 250,000 schools with more than 50 million students and 2.78 million teachers, is managed by two ministries: the Ministry of National Education (MoNE), which is responsible for 84 per cent of schools and the Ministry of Religious Affairs (MoRA), which manages the remaining 16 per cent (Jalal, Samani, Chang, Stevenson, Bagatz, \& Negara, 2009; World Bank, 2007). The educational system in Indonesia implements a 6-3-3-4 school-based education structure), comprising six years of primary school, three years of junior high school, and three years of senior high school, and four years for an undergraduate university degree. Since 1994, the 
Indonesian government has declared a system of nine-year basic education. The policy for this requires all Indonesian children who are between 7 and 15 years old be provided with a basic education comprising primary and junior secondary school education (Azkiyah \& Mukminin, 2017). After finishing their basic education, all children may continue their next level of education to senior secondary schooling consisting of two paths: general and technical/vocational school education. Furthermore, they may continue to higher education, which is an extension of secondary education and consists of academic and professional education (Azkiyah \& Mukminin, 2017; Jalal et al., 2009).

The educational system in Indonesia used to have a centralised and bureaucratic mode, as introduced by the Dutch as the colonial power. However, the downfall of Suharto's regime in May 1998 had meaningfully changed the Indonesian education policy from centralisation to decentralisation. The change was due to the emergence of the Law No.22/1999 (later reviewed by the Law 32/2004) on 'Local Government' (provinces and districts), which was officially implemented in January 2001. Both laws describe the relationship between the central government and local governments in their powers and authorities regarding education. Both laws have logical consequences requiring educational administration, management and leadership, goals, budgets, personnel, structure, and curriculum be adapted to the soul and the spirit of autonomy. The central government introduced the idea of educational decentralisation through both laws; however, in fact, the curriculum remains centralised as described in the following.

\section{The History of the Indonesian National Curriculum Policies}

The history of Indonesian curriculum has changed over the years. Since independence in 1945, the nation's educational curriculum has changed several times, in the years of 1947, 1952, 1962, 1968, 1975, 1984, 1994, 2004, 2006, and 2013. All Indonesian curricula have been designed in accordance with Indonesian national principles (the so-called Pancasila) and the 1945 Constitution of Indonesia ("MoNE", 2012).

The 1968 curriculum policy and before - The first Indonesian curriculum was the 1947 curriculum known as Rencana Pelajaran (Learning Plans). Hien (1962) stated that the 1947 curriculum was outlined into three main categories: courses, learning hours, and learning materials. It was established to reform Indonesian education from the influence of the Netherlands-based educational system aiming to produce students with character (Dewantara, 
1977; Hien, 1962). In addition, the content of the curriculum focused on character education, state consciousness, and community awareness. There were 16 courses taught, including the Indonesian language, local languages, algebra, natural science, life science, earth science, history, drawing, writing, art, handwork, female art, physical education, hygiene and health, and character education ("MoNE", 1996). Religious instruction was then introduced and added to the 1947 curriculum in 1951 ("MoNE", 1954).

The 1947 curriculum was revised in 1952 through the Indonesian act No. 4 ("MoNE", 1954). This act was first established to determine Indonesian educational provisions on curriculum, teachers, schooling, school fees, supervision, school holidays, and the relationship between school and students' parents. The articles of the act also included the Indonesian educational goals, and some courses were listed, namely religious teaching, physical education, and the national language (Indonesian). In brief, the stated purpose of the act was to produce wise citizens who were democratic and accountable for the welfare of society and the land. The curriculum was then named Rencana Pembelajaran Terurai (Detailed Learning Plan) 1952.

In 1964, the new revision of the 1952 curriculum had been proposed for the betterment of the Indonesia educational system through the Indonesian Ministry of Education Decree No. 2/1962 (Gunawan, 1986; "MoNE”, 1996). The curriculum, Rencana Pendidikan (Education Plan), focused on the development of patriotism and nationalism, which was aimed at orienting national, international, and religious values to improve students' intelligence, emotion, and physiques. Courses were classified within five groups: morality, intelligence, emotion, skills, and physique. More emphasis in primary education was placed on the development of general knowledge and practical, functional activities (Gunawan, 1986).

The next curriculum reformation happened in 1968 with Kurikulum (Curriculum) (Hien, 1962; "MoNE", 1996). This reformation was in line with the political reformation from President Soekarno's 'Old Order' to President Soeharto's 'New Order'. In this curriculum policy, basic views and concepts regarding the Indonesian educational foundation, objectives, and contents were reformulated ("MoNE", 1996). The education foundation was Pancasila (the five principles), and the objective of the curriculum was to develop Indonesian people who applied the spirit of Pancasila. The objective of the education stated in this curriculum was to solidify Indonesian students' morality, mentality, and faith, and to enhance the students' intelligence and skills as well as to develop their physical condition ("MoNE", 1996). English was introduced as the first foreign language course taught in the Indonesian educational system, along 
with other courses, such as history, geography, civic, algebra, and natural science ("MoNE", 1996).

The 1975, 1984, and 1994 curriculum policies - The Indonesian Ministry of Education established a new curriculum, the 1975 curriculum, to replace the previous one, the 1968 curriculum. It was issued on January 15, 1975, by the Decree of Education Minister No.008d/U/1975 and oo8e/U1975. The curriculum was the first in Indonesia developed based on theory-based processes and procedures of curriculum development (Bobbit, 1981). However, the development of the 1975 curriculum continued to be influenced by political aspects because almost every curriculum in that era was affected by politics (Apple, 1979). This curriculum was designed to develop the quality of the Indonesian national education. This curriculum was an objective-oriented guide for teachers who needed to understand students' objective in learning; knowledge, science, or skills to engage active learning in the instructional activities; it was named Cara Belajar Siswa Aktif (Student Active Learning Method) (Gunawan, 1986; Hasan, 1984; "MoNE", 1996). The integrated approach began to adapt, as did the structuralism philosophy, which was set as the foundation of the curriculum. The 1975 curriculum was influenced by behavioural psychology that emphasised the stimulus to response and training ("MoNE", 1975). The significant change of the curriculum content relied on the local language, which was shifted to become an optional course. In addition, the vocational schools' system, curriculum, and management were covered by this break-through curriculum (Gunawan, 1986; Hasan, 1984; "MoNE"1996).

Almost a decade later, a new curriculum was established to rectify the 1975 curriculum. It was called Kurikulum 1984. There were no significant changes in this curriculum due to the same political situation. However, one additional compulsory course, part of a history course, was introduced; it was named Pendidikan Sejarah Perjuangan Bangsa (Education History of the National Struggle), which focused on Indonesia's history of independence (Hasan, 1984; "MoNE", 1996). Additionally, local language was reintroduced as a compulsory course within this curriculum. The Cara Belajar Siswa Aktif (Student Active Learning Method) was still applied in the 1984 curriculum as a continuation of the 1975 curriculum to provide students' with active learning and to focus on students' communicative competence (Gunawan, 1986; Hasan, 1984; "MoNE", 1996).

In 1994, the 1984 curriculum was revised based on the Indonesian Act No. $2 / 1989$ about the Indonesian national educational system (Indonesian Republic, RoI, 1989). There were no significant changes or revisions from the 
previous curriculum. However, a few changes were made to the history course because it was not considered a comprehensive course for the 1984 curriculum and was revised to be more comprehensive. Pendidikan Sejarah Perjuangan Bangsa (Education History of the National Struggle) as an additional compulsory course introduced in 1975 was adapted and updated in the 1994 curriculum (Hasan, 2007; "MoNE”, 1994, 1996). Science courses dominated in this curriculum, compared to social science courses: this reflected the government's priority to develop more science-based education in embracing $20^{\text {th }}$-century education (Habibi, Mukminin, Sulistiyo, \& Sofwan, 2017; Hasan, 2007).

The Competence-Based Curriculum (CBC) or the '2004 Curriculum' was applied as a response to the structural change of the Indonesian government system from a centralised to a decentralised government, stated in Act No. 22 and 25 of 1999 about 'Otonomi Daerah (local autonomy)' or regional autonomy (Bjork, 2005; Kristiansen, 2006). Technically, the CBC was established with three levels of competencies: (1) competence of graduates: students should have certain levels of competence after they complete a certain level of education; (2) general competencies: the competencies required for students to accomplish certain subjects at particular educational levels; (3) basic competence: the competencies that should be possessed students when they follow a particular subject at a particular time (Habibi et al., 2017; "MoNE", 2003).

Unlike the previous changes of the Indonesian curriculum, which took more or less 10 years to revise, the 2004 curriculum was replaced two after years it was introduced by the new curriculum known as 'School-Based Curriculum' or the 2006 curriculum (Habibi et al., 2017; “MoNE”, 2005; Raihani, 2007). It was developed by the operational and implemented in each educational unit (school). There was no essential difference between the two curriculums. However, the 2006 curriculum complied various national education standards to ensure the educational achievement for the students: (1) content standard, (2) process standard, (3) graduate competence standard, (4) educational personnel standard, (5) facilities and infrastructure standard, (6) management standard, (7) financial standard, and (8) educational assessment standard ("MoNE", 2005; Raihani, 2017). Two of the eight national education standards, the content standards and the graduates' competence standards were the primary references for the education unit in developing the curriculum ("MoNE", 2005)

The most recently implemented curriculum is the 2013 curriculum of K-13 (Habibi, et al., 2017; "MoNE", 2012; Raihani, 2017). In this curriculum, there are four educational standards amended by Indonesian Government Regulation No. $32 / 2013$; 1) the standard of content, 2) the standard of graduate competency, 3) the standard of process, and 4) the standard of evaluation 
("MoNE", 2012). The Indonesian curriculum has been changed with an integrative-thematic concept implemented in the junior and senior high schools' levels (ibid.). The idea of the 2013 curriculum is a response to a number of critics on the gap between expectations and results. In this case, the students are expected to focus more on the cognition process rather than moral character, which could produce bad behaviour. In addition, the preparation of the curriculum implementation was still limited, which caused some problems regarding teachers' competence, evaluation process, school facilities, and materials (Febriya \& Nuryono, 2014; Gershon, 2011; Habibi et al., 2017).

\section{Discussion}

\section{Exclusive and Inclusive Curriculum}

In this part, we will discuss the definitions of exclusion, inclusion, and curriculum and then, the definitions of exclusive and inclusive curricula. Ryan's (2006) definition of exclusion refers to 'refuse to admit, consider, include; keep from entering or being; reject; bar; put out; force out; expel; or banish' (p. 6). Following this definition, when applied to social institutions like schools, it will become more complex. At the school level, students might be excluded physically, academically, and socially. In terms of physical exclusion, students may experience 'suspension and expulsion' (Ryan, 2006, p. 6). Academically, they may be excluded from the learning process because they have no cultural capital such as 'the ability to talk, act, and think in particular ways' (Ryan, 2006, p. 7) and they may be excluded given that schools favour particular knowledge, languages, values, perspectives, and voices of the dominant groups (Banks, 2002; Bennett, 2003; McMahon, 2003; Nieto \& Bode, 2008; Ryan, 2006). In addition, students are excluded socially in relation to limited access to various activities, such as extracurricular activities or programmes in schools.

From the definition of exclusion, it can be stated that the definition of inclusion applied to school is related to the situations in which students, regardless of their characteristics, are included physically, academically, and socially (Ryan, 2006). In terms of academic matters, students' values and perspectives are taken into account. In this sense, students feel that they belong in the school. Nieto and Bode (2008) stated, 'When students feel connected to school, they identify as learners, and they have a far greater chance of becoming successful learners' (p. 340).

In relation to curricula, various definitions exist. Broadly, a curriculum can be defined as something related to the experiences, both overt and covert, 
that students have in school (Bennett, 2003; Oenstein \& Hunkins, 1998). Oenstein and Hunkins (1998) specifically defined a curriculum 'as a plan for action or a written document that includes strategies for achieving desired goals and ends' (p. 10). Additionally, Nieto and Bode (2008) defined that curriculum was related to 'what should be learned and under what conditions it is to be learned' (p. 127). Given that the curriculum is related to what is important for students to know, it includes 'the knowledge, attitudes, and traditions valued in society' ( $\mathrm{p}$. 127). Following the definition of curriculum and of inclusion, for the purpose of this paper, an inclusive curriculum is defined as one that focuses on the planned experiences in school that are intended to develop and provide students with understanding, values, perspectives, attitudes, knowledge, skills, and behaviours needed to participate 'within their ethnic cultures, within the mainstream cultures, and within and across other ethnic cultures' (Banks, 2002, p. 40).

\section{Components of the Inclusive Curriculum}

The current challenges for schools and teachers related to an inclusive curriculum are not only to include various perspectives into the curriculum but also to involve students' voices and experiences as a source for learning rather than controlling them in teaching and learning processes (Tetreault, 2003). Following the definition of an inclusive curriculum above, which is defined as one that focuses on the planned experiences in school that are intended to develop and provide students with understanding, values, perspectives, attitudes, knowledge, skills, and behaviours needed to participate 'within their ethnic cultures, within the mainstream cultures, and within and across other ethnic cultures' (Banks, 2002, p. 40), the question is what are the characteristics of an inclusive curriculum? We will adopt Bennett's (2003) ideas regarding the characteristics of an inclusive curriculum, although she did not specifically mention an inclusive curriculum, but a multicultural curriculum; she proposed six major components of a multicultural curriculum, which can be adopted to develop an inclusive curriculum. The six components are developing various historical perspectives, developing cultural awareness, developing intercultural competence, combating racism, sexism, and all forms of prejudice and discrimination, increasing awareness of the state of the planet and global dynamics, and building social action skills (Bennett, 2003).

By adopting the six components, an inclusive curriculum should first enable students to develop their various historical perspectives, which refer to 'the knowledge and understanding of the heritage and contributions of diverse nations and ethnic groups, including one's own' (Bennett, 2003, p. 305). This 
component is intended to raise students' awareness of the past and current experiences among various nations and ethnic groups (Banks, 2002; Nieto \& Bode, 2008).

The second component is to develop students' cultural awareness. It is related to the recognition and awareness of the variety of ideas and practices found around the world and 'some recognition of how one's own thoughts and behaviours might be perceived by members of differing nations and ethnic groups' (Bennett, 2003, p. 305).

The third component of an inclusive curriculum is to strengthen students' intercultural competence, which is related to the skills of students to interpret intentional communications (languages), some unconscious signs, and customs or traditions that are not similar to theirs (Bennett, 2003).

Another critical component is to combat racism, sexism, and all forms of prejudice and discrimination by teaching students specific humanistic, moral, and democratic values such as the negative sides of racism, stereotypes, and prejudices (Banks, 2002; Bennett, 2003; Nieto \& Bode, 2008). This component is intended to provide students with antiracist behaviours and attitudes based on the consciousness of historical and current evidence of individual, institutional, and cultural racism or discrimination in one's own country and elsewhere in the world (Bennett, 2003; Nieto \& Bode, 2008).

The fifth component is to increase students' awareness of the state of the planet and global dynamics by teaching and providing them with knowledge about the current world conditions and developments (Bennett, 2003). This will motivate students to become involved in global society regarding health, poverty, war, and conflicts.

The last component of an inclusive curriculum is related to building students' social action skills, which consist of the knowledge, attitudes, perspectives, and behaviours necessary to participate in resolving significant problems not only in their own country but also in the rest of the world (Banks, 2002; Bennett, 2003).

\section{What should be reformed to create an inclusive curriculum?}

If included in an inclusive curriculum, the six components will help schools and teachers not only to make adjustments of curriculum and instruction to the uniqueness and various needs of students from various cultural, ethnic, and social-class groups but also to provide students with critical thinking, giving students various perspectives or ways of viewing issues and problems or seeing the globe (critical pedagogy). Through critical pedagogy, students are 
encouraged to 'take risks, to be curious, and to questions [...] to seek their own answers' (Nieto \& Bode, 2008, p. 56). McMahon (2003) stated, 'Critical pedagogy can serve as a means of opening the door and inviting all students to fully engage' (p. 262). They are empowered and engaged in the learning process.

However, those components of an inclusive curriculum will not take place, if the school variables such as assumptions, values, beliefs, structures, programmes, and policies, which favour the elite groups, are not radically reformed or restructured. School variables that must be restructured are first, the school staff's attitudes, perceptions, and low expectations for language minority students, low-income students, working-class students, and students of colour (Banks, 2002; Bennett, 2003; McMahon, 2003; Nieto \& Bode, 2008; Ryan, 2006).

The second variable is the formalised curriculum, instructional media, and the hidden curriculum that favour the traditional and mainstream knowledge and voices, such as bias in textbooks and other instructional media (Banks, 2002; Bennett, 2003; McMahon, 2003; Nieto \& Bode, 2008; Ryan, 2006).

The third reform is related to the learning, teaching, and cultural styles that are practised in the school, which tend to favour the dominant styles. This reform is based on the assumption that every child has a different style or preference for learning. For example, 'Some work well in groups; others prefer to work alone; some need absolute quite in order to concentrate' (Bennett, 2003, p. 185). Consequently, when differences in learning preference are not taken into consideration by teachers, they can lead to school failure or an achievement gap (Banks, 2002; Nieto \& Bode, 2008).

The fourth school variable is the languages and dialects that are used in school. Ryan (2003) stated that the styles of interaction and communication frequently excluded language minority students, low-income students, and working-class students from school and classroom activities. For example, although standard English must be taught to all students, schools and teachers should use language minority students, low-income students, and workingclass students' first languages and dialects to assist them in learning standard English and in achieving high academic standard (Banks, 2002; Bennett, 2003; McMahon, 2003; Nieto \& Bode, 2008; Ryan, 2006). The miscommunication between teachers and students may result in school failure, which may be unavoidable if the reform is not taken (Banks, 2002; Nieto \& Bode, 2008).

The last reform should deal with unfair assessment and testing procedures. Nieto and Bode (2008) asserted, 'Another practice that impedes equity in schools is the uncritical use of standardized testing, particularly when employed to sort students rather than to improve instruction' (p. 122). They further stated that standardised test scores had been used to segregate and sort 
students, particularly students with cultures and languages that are not similar to the mainstream. In addition, such policies may lead language minority students, low-income students, and working-class students to be underrepresented in gifted and talented classes (Banks, 2002). Standardised testing may lead schools to force teachers to 'teach to test' and make it impossible to develop an inclusive curriculum that will address the diverse needs of various students. For example, a study on the use of the national standardised test in Indonesia by Mukminin, et al. (2013) found that the use of the test had brought about adverse unintended consequences to the curriculum and instruction, teaching and learning, teacher motivation, student motivation, less attention to non-tested disciplines, and widespread cheating. To guide the reform from the exclusive and inclusive curriculum, the kind of prospective leadership there should be will be discussed in the following.

\section{Inclusive Leadership: The ASPIRE Model}

Various models of educational leadership have been proposed, such as situational leadership focusing on leaders that should adapt to various situations (Northouse, 2007) and transformational leadership, related to a process that changes and transforms people through idealised influence, inspirational motivation, and individualised consideration (Burns, 1978; Northouse, 2007). However, in terms of transformational leadership, Ryan (2003) stated, 'Transformational leadership could, at least in principle, be pursuing exclusive ends' (p. 52). In addition, McMahon (2007) wrote, 'transformational leadership fails to question the morality of the organizational goals of education and the means by which they are achieved' (p. 685). These models of leadership rely only on leaders to make changes. When applied to the school setting, these models mostly depend on school staff or favour school principals as sole leaders.

What kind of educational leadership do we need to move from an exclusive curriculum and to develop an inclusive curriculum? To reform schools from the exclusive to inclusive curriculum, educational leadership may not be successful if it relies on particular individuals or principals. In their article, Framing equitable praxis: Systematic approaches to building socially just and inclusionary educational communities, McMahon and Armstrong (2006) proposed and presented a polyfocal approach to school leadership. They called it 'the ASPIRE model'. It is 'a comprehensive systematic model whereby individuals, schools, and systems can generate positive, sustainable change in their daily interactions with minoritized students and their families with urban schools' (p. 305). Interestingly, this framework does not privilege particular individuals 
as leaders in school. Rather, it considers leadership to exist at all levels in school. 'Leaders include not only school staff but also students, their parents and guardians, and members of the local community and leadership embedded in relations between and among actors' (p. 306).

The ASPIRE model, consisting of assessment, synthesis, planning, implementation, review, and evaluation (McMahon \& Armstrong, 2006), has great potential to be employed to reform an exclusive curriculum because it involves all actors in the decision-making process in school. The involvement of all individuals at every level will enable identifying and interrogate the root causes that exclude language minority students, low-income students, and working-class students academically and socially from school programmes and activities reflected on the exclusive curriculum. In addition, the participation of parents and community in developing what knowledge their children should know will bridge the incongruence between home and school cultures such as 'languages, values, behaviour styles, and perspectives' (Banks, 2002, p. 51). The parents and community involvement in student learning are essential and the lack of their involvement will influence student achievement. Ladson-Billings (2006) wrote, 'We lack complex understandings of how individual, family, community, school, and societal factors interact to create school failures for some students' (p. 106).

In addition, the strength of the model is that it employs 'multiple lenses to examine equity practices at the individual, institutional, and system levels' (McMahon \& Armstrong, 2006, p. 305). By examining the attitudes, behaviours, and practices at the individual, institutional, and system levels, the ASPIRE model will potentially enable all actors at all levels to work together to execute 'a fundamental examination of the goals, values, and purposes of schools

and a reconstruction of them' (Banks, 2002, p. 40). In short, the ASPIRE model with its six overlapping phases will allow all leaders at all levels to address and reform all school variables above such as the issues of low expectations, the differences in learning, teaching, and cultural styles, the hidden curriculum, biases in textbooks, and instructional media, and differences in languages and dialects. The reforms on such school variables are required in order to develop an inclusive curriculum.

\section{Moving from an Exclusive to Inclusive Curriculum in Indonesia}

Developing all students' intellectual, social, and personal potentials to their highest level (Nieto \& Bode, 2008; Bennett, 2003) by providing them with an equitable, equal, and high-quality education will not become a reality (Nieto 
\& Bode, 2008; Banks, 2002) if the curriculum still privileges the elite or dominant groups, while excluding the other groups, particularly students whose cultures and languages are different from the mainstream (Nieto \& Bode, 2008; Ryan, 2003, 2006).

The exclusive curriculum tends to exclude students from the non-mainstream groups physically, academically, and socially from various activities (Ryan, 2003, 2006). Schools should be reformed from an exclusive to inclusive curriculum, which is defined as the one that focuses on the planned experiences in school that are intended to develop and provide students with understanding, values, perspectives, attitudes, knowledge, skills, and behaviours needed to participate 'within their ethnic cultures, within the mainstream cultures, and within and across other ethnic cultures' (Banks, 2002, p. 40). An inclusive curriculum should address at least the six issues: developing various historical perspectives, developing cultural awareness, developing intercultural competence, combating racism, sexism, and all forms of prejudice and discrimination, increasing awareness of the state of the planet and global dynamics, and building social action skills.

Those six issues may not be achieved if the current school variables such as assumptions, values, beliefs, structures, programmes, and policies, which favour the mainstream groups, are not thoroughly reformed or restructured. In particular, reform is essential to address issues such as low expectations, the differences in learning, teaching, and cultural styles, the hidden curriculum, biases in textbooks, and instructional media, and differences languages and dialects. However, to lead the reform, we cannot rely on traditional models of school leadership, which tend to privilege particular individuals or leaders. Consisting of assessment, synthesis, planning, implementation, review, and evaluation, the ASPIRE model is one potential model of school leadership to reform the current school variables (McMahon \& Armstrong, 2006). This model requires leaders to include actors, such as school staff, family, community, guardians, and students. By using this model, the reform will enable all actors to interrogate and interrupt the continuation and maintenance of the dominant values and perspectives in school in order to develop an inclusive curriculum, which serves various needs of students from various backgrounds and which facilitates them to succeed academically and socially.

\section{Conclusion}

In Indonesia, the curriculum and its components (e.g., books and learning materials) are centralised and generalised for all students across the country. 
However, for the underprivileged schools and children coming from the unfortunate, rural, and remote districts, the curriculum and its components might lead them to difficult situations as their characteristics, values and perspectives are excluded from the curriculum (Muazza, Mukminin, Habibi, Hidayat, \& Abidin, 2018). In other words, the exclusive curriculum might not develop and provide underprivileged schools and children with understanding, values, perspectives, attitudes, knowledge, skills, and behaviours facilitating them to participate 'within their ethnic cultures, within the mainstream cultures, and within and across other ethnic cultures' (Banks, 2002, p. 40). This kind of curriculum might exclude underprivileged students physically (suspension and expulsion), academically (excluded from learning processes) and socially (their characteristics are excluded). Therefore, the exclusive curriculum should be reformed to create an inclusive curriculum consisting of six components including developing various historical perspectives, developing cultural awareness, developing intercultural competence, combating racism, sexism, and all forms of prejudice and discrimination, increasing awareness of the state of the planet and global dynamics, and building social action skills. To guide the reform from an exclusive and inclusive curriculum, one promising type of school leadership is the ASPIRE model (assessment, synthesis, planning, implementation, review, and evaluation). The ASPIRE model facilitates school leaders to include all school actors (school staff, family, community, guardians, and students) to develop an inclusive curriculum serving numerous demands of students from diverse backgrounds so that they succeed academically and socially inside and outside school.

\section{Acknowledgements}

We would like to thank the CEPS Journal editors and anonymous reviewers for their help in improving our manuscript.

\section{References}

Apple, M. W. (1979). Ideology and curriculum. London, UK: Routledge. Azkiyah, S. N., \& Mukminin, A. (2017). In search of teaching quality of student teachers: The case of one teacher education program in Indonesia. Center for Educational Policy Studies Journal, 7(4), 105-124.

Banks, J. A. (2002). An introduction to multicultural education. Boston, MA: Pearson and AB Longman.

Bennett, C. I. (2003). Comprehensive multicultural education: Theory and practice. Boston, MA: 
Pearson and $\mathrm{AB}$ Longman.

Bjork, C. (2005). Indonesian education: Teachers, schools, and central bureaucracy. London, UK:

Routledge.

Bobbitt, J. F. (1981). The curriculum. Boston, MA: Houghton Mifflin.

Burns, J. M. (1978). Leadership. New York, NY: Harper and Row Publishers.

Dewantara, K. H. (1977). Karya Ki Hadjar Dewantara bagian pertama [The work of Ki Hadjar

Dewantara in the first part]. Yogjakarta: Majelis Luhur Persatuan Taman Siswa.

Febriya, R. W., \& Nuryono, W. (2014). Survei tentang persepsi dan kesiapan konselor terhadap

bimbingan dan konseling berdasarkan kurikulum 2013 di SMA Surabaya selatan [Survey on perception and readiness of counsellor on guidance and counselling Based on the 2013 Curriculum in senior high school in South Surabaya]. Journal BK, 4(3), 1-10.

Gershon, W. S. (2011). Introduction towards a sensual curriculum. Journal of Curriculum Theorizing, $27(2), 1-16$.

Gunawan, A. H. (1986). Kebijakan-kebijakan pendidikan di Indonesia [Educational policies in Indonesia]. Jakarta: Bina Aksara.

Habibi, A., Mukminin, A., Sofwan, M., \& Sulistiyo, U. (2017). Implementation of classroom management by English teachers at high schools in Jambi, Indonesia. Studies in English Language and Education, 4(2), 172-189.

Hasan, S. H. (2007). Perkembangan kurikulum: Perkembangan ideologis dan teoritik pedagogis (19502005) [Curriculum development: Pedagogical ideological and theoretical developments]. Retrieved from www.geocities. ws/konferensinasionalsejarah/s_hamid_hasan

Hasan, S. H. (1984). An evaluation of the 1975 secondary social studies curriculum implementation in Bandung municipality (Unpublished doctoral dissertation). Sydney: Macquarie University.

Hien, T. K. (1962). English language instruction in Indonesia (Unpublished Thesis). Malang: FKIP Universitas Airlangga.

Jalal, F., Samani, M., Chang, M. C., Stevenson, R., Ragatz, A. B., \& Negara, S. D. (2009). Teacher certification in Indonesia: A strategy for teacher quality improvement. Jakarta: Department of National Education.

Kamil, D., \& Mukminin, A. (2015). Indonesian students' multicultural awareness in homogeneously and heterogeneously populated schools and multicultural education policy. Asia-Pacific Collaborative Education Journal, 11(1), 1-16.

Kamil, D., Mukminin, A., Jamin, A., Yusuf, M., \& Idrus, A. (2013). Curriculum orientation and teaching conception among Islamic elementary public school teachers in Indonesia: A Rasch analysis approach. Asia-Pacific Collaborative Education Journal, 9(1), 1-13.

Kamil, D., Mukminin, A., Ahmad, S. I., \& Kassim, N. L. (2018). Fighting corruption through education in Indonesia and Hong Kong: comparisons of policies, strategies, and practices. $\mathrm{Al}$ Shajarah: Journal of the International Institute of Islamic Thought and Civilization (ISTAC), 155-190. Kristiansen, S. (2006). Decentralising education in Indonesia. International Journal of Educational Development, 26(5), 513-531. 
Ladson-Billings, G. (2006). It's not the culture of poverty: It's the poverty of culture: The problem with teacher education. Anthropology and Education Quarterly, 37(2), 104-109.

McMahon, B. (2007). Educational administrators' conceptions of whiteness, anti-racism and social justice. Journal of Educational Administration, 45(6), 684-696.

McMahon, B. (2003). Putting the elephant in the refrigerator: Student engagement, critical pedagogy and antiracist education. McGill Journal of Educational Research, 38(2), 257-273.

McMahon, B., \& Armstrong, D. (2006). Framing equitable praxis: Systemic approaches to building socially just and inclusionary communities. In D. Armstrong \& B. McMahon (Eds.), Inclusion in urban educational environments: Addressing issues of diversity, equity, and social justice (pp. 301-322).

Charlotte, NC: Information Age.

MoNE (Ministry of the National Education). (1954). Dasar pendidikan dan pengadjaran [Educational and teaching basis]. Jakarta: Kementerian Pendidikan.

MoNE (Ministry of the National Education). (1996). Lima puluh tahun perkembangan pendidikan di Indonesia [Fifty years of Indonesian education development]. Jakarta: Badan Penelitian dan Pengembangan Pendidikan dan Kebudayaan Depdiknas.

MoNE (Ministry of the National Education). (2012). Pengembangan kurikulum 2013 [The 2013 curriculum development]. Jakarta: Kementerian Pendidikan.

MoNE (Ministry of the National Education). (1968). Kurikulum sekolah menengah atas (SMA)

[General high school curriculum]. Jakarta: Kementerian Pendidikan.

MoNE (Ministry of the National Education). (2003). Undang-Undang 20/2003 tentang sistem

Pendidikan Nasional Indonesia [Indonesian Government Act No. 20/2003 about Indonesian National Education]. Jakarta: Kementerian Pendidikan.

MoNE (Ministry of the National Education). (2005). Peraturan Pemerintah Republic Indonesia Nomor 19 Tahun 2005 tentang Standar Nasional Pendidikan [Indonesian Government Regulation No. 19/2005 about National Education Standards]. Jakarta: Kementerian Pendidikan.

MoNE (Ministry of the National Education). (2012). Kurikulum 2013: Bahan uji public [The 2013 curriculum: Public review draft]. Jakarta: Kementerian Pendidikan.

Mukminin, A. (2012). Acculturative experiences among Indonesian graduate students in US higher education: Academic shock, adjustment, crisis, and resolution. Excellence in Higher Education, $3(1)$, $14-36$.

Mukminin, A., Haryanto, E., Makmur, Failasofah, Fajaryani, N., Thabran, Y., et al. (2013). The achievement ideology and top-down national standardized exam policy in Indonesia: Voices from local English teachers. Turkish Online Journal of Qualitative Inquiry, 4(4), 19-38.

Mukminin, A., \& Mcmahon, J. B. (2013). International graduate students' cross-cultural academic engagement: stories of Indonesian doctoral students on an American campus. The Qualitative Report, 18(35), 1-19.

Muazza, Mukminin, A., Habibi, A., Hidayat, M., \& Abidin, A. (2018). Education in Indonesian Islamic boarding schools: Voices on curriculum and radicalism, teacher, and facilities. The Islamic Quarterly, 62(4), 507-536. 
Mukminin, A. (2019). Acculturative experiences among Indonesian graduate students in Dutch higher education. Journal of International Students, 9(2), 488-510. Retrieved from https://doi. org/10.32674/jis.voio. 265

Nieto, S., \& Bode, P. (2008). Affirming diversity: The socio-political context of multicultural education. Boston, MA: Pearson and AB Longman.

Northouse, P. G. (2007). Leadership: Theory and practice. Thousand Oaks, CA: Sage Publications. Olmedo, I. M. (2003). Accommodation and resistance: Latinas struggles for their children's education. Anthropology and Education Quarterly, 34(4), 373-395.

Ornstein, A. C., \& Hunkins, F. P. (1998). Curriculum: Foundations, principles, and issues. Boston, MA: Allyn \& Bacon.

Raihani, R. (2007). Education reforms in Indonesia in the twenty-first century. International Education Journal, 8(1), 172-183.

Raihani, R. (2017). Education for multicultural citizens in Indonesia: Policies and practices. Compare: A Journal of Comparative and International Education, 1-18. doi:10.1080/03057925.2017.1399250 Ryan, J. (2006). Exclusion in urban schools and communities. In D. Armstrong \& B. McMahon, (Eds.), Inclusion in urban educational environments: Addressing issues of diversity, equity, and social justice (pp. 3-30). Charlotte, NC: Information Age.

Ryan, J. (2003). Leading diverse schools. Dordrecht: Kluwers Academic Publishers.

Sadovnik, A. (2007). Sociology of education: A critical reader. New York, NY: Routledge.

Tetreault, M. K. T. (2003). Classrooms for diversity: Rethinking curriculum and pedagogy. In J. A.

Banks \& C. A. M. Banks (Eds.), Multicultural education: Issues and perspectives (pp. 152-173). San Francisco, CA: Jossey-Bass.

World Bank. (2007). Investing in Indonesia's education: Allocation, equity, and efficiency of public expenditures. Jakarta: World Bank Office.

World Bank. (2006). Potential for significant equity, efficiency and quality improvement: Teacher employment and deployment in Indonesia. Jakarta: World Bank Office.

\section{Biographical note}

Amirul Mukminin, PhD, is an associate professor at the Graduate School, Faculty of Education, Jambi University, Indonesia. He is particularly interested in educational policy, international education policy, teacher policy reforms, the standardized exam policy reforms, English/Indonesian language policy reforms, Islamic schools and pesantren, and bilingual/multilingual education policy, which influences educational outcomes for underachieving student populations and family. 
Aкhmad Habibi, $\mathrm{PhD}$, is a faculty member at the Faculty of Education, Jambi University, Jambi, Indonesia. He received a full $\mathrm{PhD}$ scholarship from the Indonesian Endowment Fund for Education, the Indonesian Government to pursue his $\mathrm{PhD}$ at University of Malaya, Malaysia. His research interests are educational technology and instruction, Islamic schools and pesantren, English language teaching, language policy and teacher policy.

Lantip Diat Prasojo, $\mathrm{PhD}$, is a full professor in the field of educational management and administration at the Graduate School, Yogyakarta State University, Yogyakarta, Indonesia. His research interests include educational management, educational curriculum, school leadership, educational technology and teacher education.

AbDullah IdI, PhD, is a full professor in the field of sociology at the Graduate School, Universitas Islam Negeri Raden Fatah, Palembang, South Sumatra, Indonesia. His research interests include educational sociology, Islamic education, schools and pesantren.

Afreni Hamidah, $\mathrm{PhD}$, is an associate professor at the Graduate School, Faculty of Education, Jambi University, Indonesia. Her research interests are science education, biology education and science education curriculum. 